\title{
LISTENING TO THEIR VOICES: WOMEN PRISONERS AND ACCESS TO JUSTICE IN MANITOBA
}

\section{Debra Parkes, Kathy Bent, Tracey Peter, and Tracy Booth*}

\begin{abstract}
The existing research into effective accountability and oversight of Canadian prisons has considered the situation of federally sentenced prisoners (that is, those serving sentences of two years or more) and has raised serious questions about their ability to access justice in the sense of having adequate and accessible means to ensure that their treatment and conditions of confinement are just and in compliance with the law. Relatively little is known about the state of oversight and legal review processes at the provincial level, where jail terms are short and prisoners' rights litigation is rare. This paper attempts to begin filling that gap in knowledge by examining the situation faced by women imprisoned in provincial jails in Manitoba. The paper first surveys the existing international and domestic laws concerning prisoners rights and avenues for redress in Manitoba, before moving on to consider why and how those mechanisms are utilized or not, by listening to the voices of women who have been incarcerated recently at the Portage Correctional Centre. Finally, the paper considers what legislative or policy changes might be made to provide access to justice for provincial prisoners, drawing on recommendations and insights from the women themselves.
\end{abstract}

La recherche qui existe au sujet de la responsabilisation et de la surveillance efficaces des prisons canadiennes a porté sur la situation de prisonniers condamnés sous le régime fédéral (c'est-àdire, ceux qui purgent des peines de deux ans ou plus) et a soulevé des questions importantes quant à leur capacité d'accéder à la justice dans le sens de disposer de moyens adéquats et accessibles pour assurer que leur traitement et leurs conditions de détention sont équitables et conformes à la loi. On connaît relativement peu quant à l'état de surveillance et des processus de recours juridique au niveau provincial, où les périodes d'emprisonnement sont courtes et les litiges au sujet des droits des prisonniers sont rares. Cet article vise à commencer à combler ce manque d'information en examinant la situation envisagée par des femmes dé-

\footnotetext{
The authors thank the Law Commission of Canada/Canadian Bar Association "Law for the Future Fund" Access to Justice Initiative for funding this community-based research through the Elizabeth Fry Society of Manitoba. The paper was authored primarily by Debra Parkes, Associate Professor, University of Manitoba and Past-President of the Elizabeth Fry Society of Manitoba, with the collaboration of Kathy Bent (candidate, Interdisciplinary PhD in Native Studies, University of Manitoba) who conducted the interviews and preliminary data analysis, Tracey Peter (Assistant Professor, Department of Sociology, University of Manitoba) and Tracy Booth (Sessional Instructor, Faculty of Social Work, University of Manitoba) who provided assistance with research methodology and oversight of the project.
} 
tenues dans les prisons provinciales au Manitoba. L'article commence par passer en revue les lois internationales et nationales existantes concernant les droits des prisonniers ainsi que les voies de réparation au Manitoba, avant de passer aux considérations à savoir pourquoi et comment ces mécanismes sont utilisés ou non, en écoutant les voix de femmes qui ont été incarcérées récemment au Portage Correctional Center. Enfin, l'article examine quelles modifications législatives ou de politiques pourraient être faites pour que les prisonniers provinciaux aient accès à la justice, en sinspirant des recommandations et de la perspicacité des femmes elles-mêmes.

\section{INTRODUCTION}

The pursuit of access to justice in any society grows from an awareness that "guarantees of rights, benefits, and entitlements and of protections under the law are meaningless if mechanisms are not in place to assure access to the means of assuring those rights and protections." ${ }^{\text {Th }}$ This paper examines the ability of provincially sentenced prisoners, ${ }^{2}$ and particularly women prisoners who make up approximately eight percent of the provincial prison population in Manitoba, ${ }^{3}$ to access justice in the sense of ensuring that their treatment and conditions of confinement are just and in compliance with the law. ${ }^{4}$ In Manitoba, it is predominantly Aboriginal women who fill the Portage Correctional Centre [PCC], comprising over $73 \%$ of the province's population of women prisoners. ${ }^{5}$ As such,

1 Ab Currie, Riding the Third Wave - Notes on the Future of Access to Justice (Ottawa: Department of Justice, Research and Statistics Division: 2000) at 1, online: Department of Justice <http://www.justice.gc.ca/en/ps/rs/rep/2000/rr00-op2/b2.html> at 1 .

2 Prisoners serving sentences of less than two years fall under provincial jurisdiction, while prisoners serving two years or more are governed by federal law.

3 "Adult correctional services, admissions to provincial, territorial and federal programs (Manitoba)," online: Statistics Canada <(Ottawa: Statistics Canada, 2006) http://www40.statcan. $\mathrm{ca} / 101 / \mathrm{cst} 01 /$ legal30i.htm>.

4 Legal aid is one aspect of access to justice for prisoners. Some studies of the availability and adequacy of provincial legal aid plans have included consideration of the situation of federally sentenced prisoners. See e.g., Lisa Addario, Six Degrees from Liberation: Legal Needs of Women in Criminal and Other Matters, (Ottawa: Department of Justice Canada, Research and Statistics Division, 2002) online: Department of Justice <http://www.canada.justice.gc.ca/en/ps/rs/ rep/2003/rr03lars-20/index.html> [Addario, Six Degrees from Liberation] and Department of Justice Canada, Study of the Legal Services Provided to Penitentiary Inmates by Legal Aid Plans and Clinics in Canada, online: Department of Justice < (Ottawa: Department of Justice Canada, Research and Statistics Division, 2002) http://canada.justice.gc.ca/en/ps/rs/rep/2003/rr03lars10 /index.html $>$. However, to the authors' knowledge, the current study is the first of its kind considering the access to justice needs of provincially sentenced prisoners.

5 In a one-day snapshot of persons in provincial custody in Manitoba on September 6, 2000, 73\% of the women were Aboriginal, which is an even more significant over-representation than the $63 \%$ of male prisoners who were Aboriginal. See Aboriginal Justice Implementation Commission, Final Report (Winnipeg: Manitoba Justice, 2001), online: Aboriginal Justice Implementation Commission <www.ajic.mb.ca>. More recent statistics broken down by gender are not available, but anecdotal reports from Elizabeth Fry Society workers at PCC indicate that the proportion of Aboriginal women is growing. For discussion of the growing over-representation 
there is a need to approach the subject of prisoners' access to justice with an awareness of the on-going impact of colonization and discrimination experienced by Aboriginal people, ${ }^{6}$ with particular effects on Aboriginal women, ${ }^{7}$ and with a goal of giving voice to Aboriginal conceptions of access to justice.

The existing research into effective accountability, oversight, and access to justice for prisoners has considered the situation of federally sentenced prisoners (that is, those serving sentences of two years or more). ${ }^{8}$ Justice Louise Arbour concluded her 1996 Report of the Commission of Inquiry into Certain Events at the Prison for Women in Kingston by saying " $[\mathrm{t}]$ he society in which many women offenders live is neither peaceful nor safe. By the time they go to prison, they should be entitled that it will be just." The "certain events" that led to the inquiry and report included the strip-searching of women prisoners by a male Institutional Emergency Response Team in full riot gear, the subsequent illegal and involuntary transfer of women to a segregated unit inside Kingston Penitentiary for men, and further illegal detention in segregation for many months. The report had as its central focus the lack of independent accountability and oversight that facilitated such seemingly inconceivable events going on as long as they did. Justice Arbour made recommendations for reform of the correctional system, but also to implement a system of judicial oversight of the integrity of federal sentences (that is, if prisoners could prove that they had been subject to illegalities, rights violations, or gross negligence, they would be entitled to a reduction of their sentence as both a sanction and compensation for the breach).

of Aboriginal women in federal prisons, see Canadian Human Rights Commission, Protecting Their Rights: A Systemic Review of Human Rights in Correctional Services for Federally Sentenced Women (Ottawa: Canadian Human Rights Commission, 2003), online: Canadian Human Rights Commission <http://www.chrc-ccdp.ca/pdf/reports/FSWen.pdf> [CHRC, Protecting their Rights].

6 See generally, Alvin Hamilton and Murray Sinclair, Commissioners, Report of the Aboriginal Justice Inquiry of Manitoba: The Justice System and Aboriginal People (Winnipeg: Queen's Printer, 1991), reporting on systemic discrimination experienced by Aboriginal people in the justice system and making the overarching recommendation for a separate Aboriginal justice system, as well as for significant reforms in areas such as policing, courts, corrections, and child welfare [Hamilton and Sinclair, Justice System and Aboriginal People].

7 See generally, Carol LaPrairie, "Aboriginal Women and Crime in Canada: Identifying the Issues," in Ellen Adelberg and Claudia Currie, eds., In Conflict with the Law: Women and the Canadian Justice System (Vancouver: Press Gang, 1993); Patricia Monture-Angus, "Aboriginal Women and Correctional Practice: Reflections on the Task Force on Federally Sentenced Women," in Kelly Hannah-Moffat and Margaret Shaw, eds., An Ideal Prison? Critical Essays on Women's Imprisonment in Canada (Halifax: Fernwood, 2000) and Patricia Monture-Angus, The Lived Experience of Discrimination: Aboriginal Women Who are Federally Sentenced (Ottawa: Canadian Association of Elizabeth Fry Societies, 2000), online: Elizabeth Fry Society <http://www. elizabethfry.ca/submissn/aborigin/aborigin.pdf>.

8 See e.g., Debra Parkes and Kim Pate, “Time for Accountability: Effective Oversight of Women's Prisons" (2006), 48 Canadian Journal of Criminology and Criminal Justice 251 and the other articles contained in (2006) 48(2) Canadian Journal of Criminology and Criminal Justice, a symposium on "Prison Oversight and Human Rights."

9 Justice Louise Arbour, Commissioner. Report of the Commission of Inquiry into Certain Events at the Prison for Women in Kingston (Ottawa: Solicitor General, 1996) at 248, online: Solicitor General Canada <http://www.justicebehindthewalls.net/resources/arbour_report/arbour_rpt. htm> [ Arbour Report]. 
This recommendation has never been implemented, but some court decisions indicate an increased willingness to give meaningful effect to prisoners' Charter and other rights. Nevertheless, access to the courts and to other forms of external accountability and oversight remains illusory for many prisoners.

Service-providers and advocates who work with women incarcerated in provincial jails (many of whom work with one of the twenty-five Elizabeth Fry Societies across the country) regularly hear about conditions and treatment that may amount to breaches of the law including, for example, long term segregation without external review, deprivation of access to Aboriginal elders and teachings, lack of access to lawyers and visits with family members, inadequate health care, and many others. They also lament the lack of awareness by jail staff and prisoners about prisoners' legal rights when attempts are made to question the treatment of prisoners.

This research attempts to begin filling that gap by first surveying the existing international and domestic laws concerning prisoners' rights and avenues for redress in one jurisdiction: Manitoba. Secondly, this paper considers why and how those mechanisms are utilized or not utilized, by listening to women prisoners themselves. The paper concludes by briefly considering what legislative or policy changes might be made to promote meaningful access to justice for provincial prisoners. The study aims to examine both law "on the books" and law "in every day life" for the women most affected, with an eye on improving the level of access to justice experienced by them.

\section{II: LEGAL LANDSCAPE}

\section{A. Canadian constitutional law}

The Canadian Constitution, including the Canadian Charter of Rights and Freedoms, ${ }^{10}$ is the "Supreme Law of Canada," which means that all law and government action must be consistent with the rights guaranteed in the Charter. ${ }^{11}$ The Charter sets out a number of rights that are important in the prison context, such as:

- freedom of religion and conscience (section 2(a));

- freedom of expression (section 2(b));

- the right to life, liberty and security of the person and the right not to be deprived thereof except in accordance with the principles of fundamental justice (section 7);

- freedom from unreasonable search and seizure (section 8);

- rights against arbitrary detention (section 9) and cruel and unusual punishment or treatment (section 12);

- the right to retain and instruct counsel without delay upon arrest and detention (section 10(b)); and

- equality rights (section 15), among others.

10 Canadian Charter of Rights and Freedoms, Part I of the Constitution Act, 1982, being Schedule B to the Canada Act 1982 (U.K.), 1982, c. 11 [ Charter].

11 Section 52 of the Constitution Act (and s. 32 of the Charter). 
Examples of successful cases brought by prisoners under the Charter include a decision that limiting remand prisoners' phone access to only collect calls violated their s. 7 right to a fair trial and their s. 11(d) presumption of innocence, ${ }^{12}$ a finding that a prisoner's s. 2(a) freedom of conscience was violated by a correctional policy to deny vegetarian meals unless the vegetarianism was linked to a religious belief, ${ }^{13}$ and a decision that excessive and unreasonable force used on a prisoner violated his s. 12 right against cruel and unusual punishment and s. 9 right against arbitrary detention, ${ }^{14}$ among others. However, many Charter claims fail, whether due to the tendency of courts to defer to correctional decision-makers, ${ }^{15}$ weaknesses in the evidence, a lack of legal aid to bring the claim, or procedural obstacles such as cases being rendered "moot" (or without a live controversy) by the time they get to court.

The problem of Charter claims evading judicial review due to mootness is particularly pronounced in the provincial imprisonment context, where sentences are by definition less than two years and are often much shorter. Even where a prisoner has a strong claim on the merits, a court may find the issue moot where the prisoner has since been released from segregation or finished her sentence altogether. ${ }^{16}$ However, some recent cases indicate a judicial willingness to take a broader view and to find an "ongoing live controversy" in prison cases, even where the prisoners have been released. For example, in refusing to declare moot a Charter challenge to the conditions of confinement at the Edmonton Remand Centre where all the litigants had since been released, the Alberta Court of Queen's Bench recently commented:

[a]n application for release from disciplinary segregation may be evasive of judicial review because the question is moot as soon as the inmate is released. Similarly, an application to quash an order of a disciplinary hearing may be mot, if the decision is voluntarily set aside. In practice, if every application for Charter relief from conditions at ERC is dismissed

12 Criminal Trial Lawyers' Association v. Alberta (Solicitor General), [2004] A.J. No. 838 (Q.B.).

13 Maurice v. Canada (Attorney General), [2002] F.C.J. No. 72 (T.D.).

14 R. v. MacPherson, [1996] N.B.J. No. 182 (S.C.).

15 For some discussion of the history of the judicial "hands off" approach, see Michael Jackson, Justice Behind the Walls: Human Rights in Canadian Prisons (Vancouver: Douglas \& McIntyre, 2002) at 49-50 and Mary Campbell, "Revolution and Counter-revolution in Canadian Prisoners' Rights” (1996), 2 Can. Crim L. Rev. 285 at 291-295. For an argument that this approach continues in the Charter era, see Debra Parkes, "A Prisoners' Charter: Reflections on Prisoner Litigation under the Canadian Charter of Rights and Freedoms," (2007) 40 U.B.C. Law Review at 629-676.

16 See e.g. Allard v. Nanaimo Correctional Centre, [2000] B.C.J. No. 1602 (S.C.) where the B.C. Supreme Court judge found serious breaches of natural justice had been committed by a correctional staff member who was adjudicating a discipline hearing. For example, the prisoner was asked to leave the room to permit confidential information being read into the record, the tape recording of the hearing contained a 3-minute blank space during this time, and the prisoner was not allowed to call witnesses because the adjudicator believed that the prisoners had probably collaborated on a story. While the decision itself was quashed, the Charter issues were found to be moot since the prisoner had since been released and was credited with his lost earned remission time. 
because the applicant has been released, the question as to whether or not his or her incarceration was in breach of the Charter will remain forever evasive of review. ${ }^{17}$

This is a promising development and one that demonstrates an understanding on the courts' part of some of the significant barriers to access to justice for prisoners.

A successful area of prisoner Charter litigation has been with respect to the right to vote. In the 2002 Sauvé decision, ${ }^{18}$ a majority of the Supreme Court of Canada struck down a law that barred prisoners serving two years or more from voting in federal elections. ${ }^{19}$ In doing so, the majority stated that prisoners are not second-class citizens, at least in relation to democratic rights. The Canadian government is not permitted to make prisoners "temporary outcasts from our system of rights and democracy." 20

The decision in Sauvé is, therefore, instructive for the stringent approach taken by the majority to each stage of the government's attempted Charter justification of prisoner disenfranchisement. For example, in rejecting the argument that a ban on federal prisoners voting is even rationally connected to the objective of "enhancing the criminal sanction," the Chief Justice strongly supported the notion of prisoners as rights-bearing citizens:

[i] ndeed, the remedy of imprisonment for a term rather than permanent exile implies our acceptance of continued membership in the social order. Certain rights are justifiably limited for penal reasons, including aspects of the rights to liberty, security of the person, mobility, and security against search and seizure. But whether a right is justifiably limited cannot be determined by observing that an offender has, by his or her actions, withdrawn from the social compact. Indeed, the right of the state to punish and the obligation of the criminal to accept punishment are tied to society's acceptance of the criminal as a person with rights and responsibilities. ${ }^{21}$

In short, these recent cases contain strong statements to the effect that the Charter rights do not stop at the prison walls.

\section{B. Manitoba law}

\section{Correctional Services Act and Regulations}

The legislation governing provincial corrections in Manitoba stands in sharp

17 Trang v. Alberta (Edmonton Remand Centre), [2004] A.J. No. 796 (Q.B.), aff'd [2005] A.J. No. 157, leave to appeal to the S.C.C. denied with costs: [2005] S.C.C.A. No. 161.

18 Sauvé v. Canada (Chief Electoral Officer), [2002] 3 S.C.R. 519 [Sauvé].

19 Canada Elections Act, R.S.C. 1985, c. E-2, ss 51 (e).

20 Sauvé, supra, note 18, at para 40.

21 Sauvé, ibid. at para. 47. 
contrast to the federal correctional legislation, the Corrections and Conditional Release Act $[C C R A],{ }^{22}$ which was overhauled in 1992 and which now provides a number of significant guiding principles and prisoners' rights, such as that correctional officials must "use the least restrictive measures consistent with the protection of the public, staff members and offenders" and that "offenders retain the rights and privileges of all members of society, except those rights and privileges that are necessarily removed or restricted as a consequence of sentence." 23 There appears to have been no similar move to bring provincial correctional law into the "Charter era." While some amendments to the Manitoba Correctional Services Act $[C S A]^{24}$ were made in 1998, the principles and purposes articulated are generally less ambitious than those in the federal CCRA. For example, the Manitoba Act does not contain specific entitlements such as rights to counsel, health care, and consultation found in the federal Act.

Instead of explicit prisoners' rights, the CSA largely confers a host of powers on correctional officials such as authorizing tests for intoxicants (s. 16), monitoring communications (s. 42), authorizing uses of force (s. 44) and the like. However, the CSA also sets out procedures for grievances, disciplinary hearings, review of segregation (solitary confinement) decisions, and appeals of such decisions, ${ }^{25}$ all of which are conducted internally by correctional staff and administration. For example, section 4(1) of the CSA provides that prisoners may be placed in segregation for "protective or preventative" reasons of safety, security, order, or for the well-being of the prisoner. Regulations under the CSA provide that prisoners are entitled to a review of the segregation decision by the superintendent of the jail or her designate within seven days (and thereafter every seven days for the first sixty days of segregation; after sixty days, she is entitled to a similar internal review every thirty days). ${ }^{26}$

\section{Human Rights Code}

The Manitoba Human Rights Code ${ }^{27}$ [Man HRC] is the province's anti-discrimination statute. It prohibits and provides remedies for discrimination in a variety of areas including in the provision of services "accessible to the public or to a section of the public, unless bona fide and reasonable cause exists for the discrimination." ${ }^{28}$ While it may seem odd, from a prisoner's perspective, to

22 R.S.C. 1992 c. 20 .

23 Ibid., sections 4(d) and 4(e) respectively. The CCRA also contains a number of specific rights such as an unqualified right to counsel in serious prison disciplinary matters (although no right to legal aid), a right to health care, and a right to notice and/or consultation concerning significant decisions other than those involving security. These rights are more specific than Charter rights and, therefore, may be more amenable to judicial review. For a discussion of the background and development of the approach in the CCRA, see Michael Jackson, Justice Behind the Walls: Human Rights in Canadian Prisons (Vancouver: Douglas \& McIntyre, 2002) at 62-67.

24 S.M. 1998 , c. 47 - Chap. 230.

25 A detailed review of the provisions for internal grievances, appeals, institutional discipline, and review of segregation can be found in our full report which was submitted to the LCC/CBA Law for the Future Fund and is on file with the authors.

26 Correctional Services Regulation, R.M. 128/99 [CSA Reg], s. 20.

27 C.C.S.M. c. H175 (“HRC”).

28 HRC s. 13(1). 
consider imprisonment to be a "service", it is clear that the government is bound by the provisions of the Man HRC in all aspects of administering "correctional services" in the province. ${ }^{29}$ As a government actor, its obligations under the Man $H R C$ overlap and intersect with the equality rights protections in the Charter.

Section 9(1) of the Man HRC defines discrimination broadly to mean the following:

- (a) differential treatment of an individual on the basis of the individual's actual or presumed membership in or association with some class or group of persons, rather than on the basis of personal merit; or

- (b) differential treatment of an individual or group on the basis of any characteristic referred to in subsection (2); or

- (c) differential treatment of an individual or group on the basis of the individual's or group's actual or presumed association with another individual or group whose identity or membership is determined by any characteristic referred to in subsection (2); or

- (d) failure to make reasonable accommodation for the special needs of any individual or group, if those special needs are based upon any characteristic referred to in subsection (2).

The "applicable characteristics" listed in s. 9(2) include ancestry, race, national origin, religion, age, sex, sexual orientation, marital or family status, source of income, political belief, and physical or mental disability.

Furthermore, the Man HRC makes it clear that discrimination can be systemic and unintentional. ${ }^{30}$ It is essential to look at the impact on an individual or group who is treated differently on the basis of one or more of the characteristics listed above. A party can be found to discriminate where it has failed to reasonably accommodate the needs of individuals or groups, which means that sometimes individuals or groups must be treated differently to be treated in a substantively equal manner. For example, where women have different needs than men, they may be entitled to services tailored to their needs which may not be available to men.

The Man HRC establishes a process whereby a complaint of discrimination is filed with the Human Rights Commission and investigated by Commission

29 In 2002, the Elizabeth Fry Society of Manitoba filed a complaint against Manitoba Justice under the HRC on behalf of women prisoners in the province, alleging systemic discrimination on the basis of sex, race, and disability concerning the facilities and conditions of confinement at PCC. The parties reached a mediated settlement in 2007; online: Elizabeth Fry Society, <http://www. efsmanitoba.org/>.

30 HRC s. 9(3). 
staff. Where merit is found in the complaint it is referred to mediation and, failing mediation, to adjudication for a hearing on the merits. A broad range of remedies ${ }^{31}$ is available to an adjudicator who finds that the $H R C$ has been breached, including ordering a party to "do or refrain from doing anything in order to secure compliance with this Code, to rectify any circumstance caused by the contravention, or to make just amends for the contravention," to pay compensatory and exemplary damages, or to require a party to adopt and implement an affirmative action program or other special program, where appropriate.

\section{Ombudsman Act}

The Office of the federal ombudsperson for prisoners, the Correctional Investigator, originally created in 1973 , has played a role in seeking to bring more accountability and transparency to correctional decision-making, as well as performing the function of alerting government and the public to some serious abuses in the federal prison system. ${ }^{32}$ In Manitoba, there is no ombudsperson designated solely for prisoners. Instead, the Manitoba Ombudsman [sic], an independent officer of the Legislative Assembly, is responsible for conducting investigations under the Ombudsman Act [Man $O A]{ }^{33}$ concerning administrative acts, omissions, or decisions on "matters of administration" of any provincial or municipal department or agency, as well as for enforcing the Freedom of Information and Protection of Privacy Act ${ }^{34}$ and the Personal Health Information Act. ${ }^{35}$ The Supreme Court of Canada has defined "matters of administration" to mean "everything done by governmental authorities in the implementation of government policy" and to "exclude only the activities of the legislature and the courts from the Ombudsman's scrutiny." 36 This broad mandate means that investigating complaints regarding correctional services is only a small part of the activities of the Manitoba Ombudsman. In addition, the Ombudsman's role is to make recommendations, ${ }^{37}$ but the office has no authority to order compliance from government.

31 HRC, s. 43(2)

32 The annual reports of the Correctional Investigator can be found on their website; online: Correctional Investigator Canada <http://sgc.gc.ca/reports_e.asp >.

33 C.C.S.M. c. O45 (“OA”).

34 C.C.S.M. c. F175.

35 C.C.S.M. c. P33.5.

36 British Columbia Development Corp. v. British Columbia (Ombudsman), [1984] 2 S.C.R. 447 at 474. Section 18(d) of the Manitoba $O A$ also excludes:

any decision, recommendation, act or omission in respect of which there is, under any Act a right of appeal or objection or a right to apply for a review on the merits of the case to any court or tribunal constituted by or under an Act of the Legislature, whether or not that right of appeal, objection or application has been exercised in the particular case and whether or not any time prescribed for the exercise of that right has expired, unless the Ombudsman is satisfied that in the particular case it would have been unreasonable to expect the complainant to resort to the tribunal or court, but in that case investigation shall not commence until after the time prescribed for the exercise of that right to appeal, object or apply, has expired. 


\section{Common Law}

The common law right of judicial review on habeas corpus grounds, whereby the state must justify any detention as lawful, dates back in English law at least to the Magna Carta in 1215 which provided that "[n]o free man shall be seized or imprisoned . . . except by the lawful judgement of his equals or by the law of the land." 38 The 2005 decision of the Supreme Court of Canada in May v. Ferndale Institution ${ }^{39}$ represents a strong affirmation of the contemporary importance of habeas corpus review in the prison context. The Supreme Court unanimously and unequivocally affirmed the right of prisoners to go to superior court on habeas corpus (thereby overturning a line of authority in provincial appellate courts which had held that habeas corpus review is not available to federal prisoners except in limited circumstances) ${ }^{40}$ Furthermore, in the course of its decision that habeas corpus must be available to federal prisoners, the court bolstered the case for enhanced judicial oversight of corrections more generally by describing the internal federal grievance procedure as woefully inadequate to protect fundamental rights and interests.

A majority of the court in May found the instant decision - a decision to reclassify Terry May and others from minimum to medium security - to be arbitrary and therefore illegal. Classification decisions are about institutional security writ large and courts have tended to defer to correctional officials in such cases. This was not so in May where the majority found the correctional authorities' refusal to disclose the "scoring matrix" for reclassification and transfer decision to the applicants and to the court at first instance to be misleading and "highly objectionable." 41 Recognizing the inappropriateness of reflexive deference to correctional decision-making, ${ }^{42}$ the majority seemed to grasp the difficulties faced by prisoner litigants in challenging the actions of authorities who hold all the power and much of the relevant evidence.

Finally, other common law doctrines, such as the principles of negligence in tort law, may provide a basis for lawsuits brought by prisoners. In a recent Federal Court decision, Tracy Curry, a prisoner at Grand Valley Institution, was awarded \$10,000 in damages for negligence and breach of her s. 10(b) Charter right to counsel after she was subjected to a body cavity search. ${ }^{43}$ The court found that her purported consent to the cavity search was obtained by inducement and was therefore invalid.

\section{International law}

The Supreme Court of Canada has held that domestic legislation must be interpreted in a manner consistent with Canada's international human rights

38 Cited in May v. Ferndale, [2005] 3 S.C.R. 209 at para. 19.

39 Ibid.

40 See e.g., Spindler v. Millhaven Institution, [2003] O.J. No. 3449 (C.A.) and the B.C. Court of Appeal decision in May v. Ferndale, [2003] B.C.J. No. 2294.

41 Supra, note 38, at para. 109-110.

42 On the flip side, the dissenting judges show a significant degree of deference to the CSC in deciding the scope of disclosure to prisoners facing reclassification and involuntary transfer, as well as in making the "individual assessment" to transfer each prisoner.

43 Curry v. Canada, [2006] F.C.J. no. 87 (T.D.). 
obligations. ${ }^{44}$ Canada has made commitments under international human rights treaties which mean that "any correctional authority should adhere to both binding and other international human rights instruments that have been approved by the state concerned before the international community." 45 As noted in the 1997 report commissioned by the Correctional Service of Canada, Human Rights and Corrections: A Strategic Model: ${ }^{46}$

The Universal Declaration of Human Rights was adopted by the United Nations General Assembly on December 10, 1948. Although it does not have the status of a binding international covenant, it is widely regarded as determining conventional international law and as the primary instrument for protecting the "inalienable," "inherent" and "fundamental" dignity of the human person. It underlies the many subsequent UN covenants and conventions that have shaped international human rights law, to which Canada is a party, in particular the International Covenant on Civil and Political Rights and the Convention Against Torture. These, among other things, provide that:

All persons deprived of their liberty shall be treated with humanity and with respect for the inherent dignity of the human person (art. 10, International Covenant on Civil and Political Rights [ICCPR]);

No one shall be subjected to torture or to cruel, inhuman or degrading treatment or punishment (art. 7, $I C C P R)$;

The penitentiary system shall comprise treatment of prisoners the essential aim of which shall be their reformation and social rehabilitation (art. 10(3), ICCPR); and

Each State shall take effective legislative, administrative, judicial or other measures to prevent acts of torture in any territory under its jurisdiction (art. 2(1), Convention against Torture and Other Cruel, Inhuman or Degrading Treatment or Punishment).

44 Most recently, in R. v. Hape, [2007] 2 S.C.R. 292, the Supreme Court stated that "courts will strive to avoid constructions of domestic law pursuant to which the state would be in violation of its international obligations, unless the wording of the statute clearly compels that result" (at para. 53).

45 Max Yalden, Human Rights and Corrections: A Strategic Model (Ottawa: Correctional Service of Canada, 1997) http://www.csc-scc.gc.ca/text/pblct/rights/human/toce_e.shtml, c. 2 [Yalden, Human rights and corrections]. 
The Report further noted that the most significant international treaty dealing exclusively with prisoners' rights is the Standard Minimum Rules for the Treatment of Prisoners [SMRs], ${ }^{47}$ to which Canada subscribed in 1975. In the course of doing so, the Canadian Delegation announced that, "in approving the instructions for the Canadian Delegation to this Congress, the Cabinet agreed that the Delegation should indicate to the Congress that Canada has adopted the Rules and will refer these for implementation to the Committee of Federal/Provincial Ministers and Deputy Ministers of Corrections." ${ }^{8}$

Therefore, while the SMRs are not actionable in a Canadian court per se, they are evidence of an international consensus on basic minimum entitlements. Canada prides itself on being a leader in human rights, yet in Manitoba and elsewhere, these basic minimum standards are not being met. For example, the $S M R s$ require that untried prisoners be kept separate from convicted prisoners, ${ }^{49}$ yet remand and sentenced prisoners are incarcerated together at the Portage Correctional Centre. The SMRs further provide that women prisoners shall be supervised only by women officers, ${ }^{50}$ yet there are male correctional officers working on the front lines at PCC. Proof that Manitoba is not meeting its obligations under the SMRs is evidence that may be relevant to determining a breach of the Charter or of other domestic law.

Of particular significance to this brief survey of international law is the fact that Article 2 of the International Covenant on Civil and Political Rights [ICCPR], to which Canada is a signatory, requires that effective remedies be provided for persons whose rights have been violated. This provision calls for every person to have their claims of human rights violations heard by a competent administrative, judicial or legislative authority. It appears that this is a right that is effectively denied to women and men in provincial jails due to the fact that the only available grievance and complaints process is internal and non-independent. In the context of federal imprisonment, the United Nations Human Rights Committee [UNHCR] made the following recommendation in its 2005 Concluding Observations made in respect of Canada's fifth periodic report on implementation of the ICCPR ${ }^{51}$ :

[Canada] should provide substantial information on the implementation of the recommendations of the Canadian Human Rights Commission as well as on concrete results achieved, in particular regarding the establishment of an independent external redress body for federally sentenced offenders and independent adjudication for decisions related to involuntary segregation, or alternative models. ${ }^{52}$

47 Resolution 663 C (XXIV) of 31 July 1957, and amended by Resolution 2076 (LXII) of 13 May 1977.

48 Yalden, Human rights and corrections, supra note 45 at c.2.

49 SMRs, s. 8(b).

50 SMRs, s. 53(3).

51 United Nations Human Rights Committee (UNHRC), Concluding Observations of the Human Rights Committee in Relation to the Report Submitted by Canada Under Article 40 of the International Covenant on Civil and Political Rights (Geneva: United Nations Human Rights Committee 85th Session, 2005) CCPR/C/CAN/CO/5.

52 Ibid., Recommendation 18. 
As briefly described above, the mechanisms for oversight and accountability are even more inadequate in the provincial correctional system in Manitoba than in the federal system which was the subject of this critique by the UNHCR.

In conclusion, the "legal landscape" for provincially sentenced prisoners in Manitoba is a significant terrain that has generally gone unmapped to date. The preceding section has aimed to compile, in summary form, a roadmap of many of the rights and remedies available to prisoners. The next section turns to the rights-holders themselves, women prisoners in Manitoba, to understand their awareness of these rights and their perspectives on access to justice. In addition to examining the "law on the books," this study seeks to understand something about the experience on the ground and, in particular, the legal consciousness of women prisoners in Manitoba.

\section{III: METHODOLOGY FOR QUALITATIVE RESEARCH}

Central to feminist and Aboriginal-based methodologies is the premise that all knowledge is partial and embedded within social discourse; as a result, no one "can speak for women [or Aboriginal People] because no such person exists except within a specific set of already gendered [and racialized] relations." ${ }^{53}$ Within this framework, listening to women's voices is vital if we are to determine the meaning behind issues of legal review for provincially sentenced prisoners - a group who are subjects of the justice system every day but whose ability to access justice is rarely considered. Such an approach typically favours qualitative methodologies. This approach is seen as the best way to listen to women's voices in order to investigate patterns that emerge from personal testimonies. For this reason, in-depth semi-structured interviews were conducted with twenty-one women who were in the community but had been incarcerated at the Portage Correctional Centre [PCC] (that is, serving sentences of two years less a day or on remand awaiting trial) within the last two years. ${ }^{54}$ PCC is the main correctional facility for women in Manitoba. In general, women prisoners make up less than 10 percent of the provincial prison population.

Consistent with qualitative methodologies, non-probability sampling was used. Because the goal was to highlight narratives from a specific group of people - criminalized women - purposive sampling was used. As such, participants were recruited with the aid of the Elizabeth Fry Society, an organization which has a long and well established history of working with women in prison and

53 Sherene Razack, "Exploring the Omissions and Silences in Law Around Race" in Joan Brockman and Dorothy E. Chunn, eds., Investigating Gender Bias: Law, Courts and the Legal Profession (Toronto: Thompson Educational Publishing, 1993) at 42.

54 Initially half the sample was to be comprised of women currently serving provincial sentences at PCC. Due to difficulties in gaining access to the jail as well as our concerns about the well-being of women speaking from inside (especially given the nature of the research topic), we elected to conduct interviews only with women from the community. We also had initially intended to have half the sample consist of women who had utilized the legal review process; however, when we began interviewing, we quickly realized that most women had not used the existing access to justice mechanisms. Further, many women felt more comfortable talking about someone they knew who had utilized the legal review process. This is understandable given the power dynamics embedded within total institutions such as prisons. 
offers many programs and services for women who are either in prison or in the community.

In Manitoba, the vast majority of women prisoners (upwards of 70 percent) are Aboriginal - a group whose cultural practices and ways of understanding justice and healing have often been marginalized by mainstream culture and law. ${ }^{55}$ As such, interviews were based on OCAP (Ownership, Control, Access, and Possession) principles, meaning:

First Nations control data collection processes in their communities. First Nations own, protect and control how information is used... The right to First Nations communities to Own, Control, Access, and Process information about their peoples is fundamentally tied to self-determination and to the preservation and development of their culture. ${ }^{56}$

As a way to adhere to OCAP principles, an Aboriginal woman research assistant was hired to conduct all interviews. Non-English language options were also made available to all First Nations participants. In addition, a summary report was written and made available to participants and community members through a feast, hosted at the Elizabeth Fry office, which included the involvement of an elder who opened and closed the feast in a Traditional way using prayer and medicines. Finally, a plain language handbook outlining prisoners' rights and practical access to justice information is being produced and will be distributed to women prisoners through the Elizabeth Fry Society.

This research is intended as an exploratory study of the experiences of provincially sentenced women in terms of their perceptions of access to justice. As outlined earlier, the main goal of this research is to survey the available mechanisms for legal review (complaints, grievances, or reviews) by provincial prisoners in Manitoba, and then consider why and how those apparatus' were or were not used. In particular, three research questions guide this work:

- What experiences do women in prison have that could be (or should be) the subject of a legal review?

- Do women in prison utilize existing legal mechanisms for redress of rights violations and other illegalities? Why or why not?

- By listening to women in prison, what recommendations do they have that would make the system more effective? What has to happen in order for their needs to be met?

Each research question will be discussed in turn, but first it is important to contextualize the women as a group in terms of who they are and how they became criminalized.

55 Hamilton and Sinclair, supra note 6 and Monture-Angus, supra note 7.

56 National Aboriginal Health Organization, “OCAP Principles” http://www.naho.ca/firstnations/ english/ocap_principles.php 


\section{IV: RESEARCH FINDINGS}

\section{A. Who are the women?}

Of the twenty-one women who participated, all reported being incarcerated at PCC over the last two years. Eight women also mentioned being jailed in the Remand Centre, four were previously incarcerated in youth detention, one had served time at the The Pas Correctional Centre, and one woman served a federal sentence. Fourteen women were in PCC for less than six months, four women spent seven months to one year, and one woman was there for almost two years. Two women's sentences were not disclosed in the interview. Seven women (thirty-three percent) reported spending time in segregation while at PCC.

The women interviewed ranged in age from twenty-four to forty-three years old (average age was thirty-five). With the exception of one Caucasian woman, all participants were Aboriginal, Inuit, or Métis. Only three women (fourteen percent) reported completing high school. Of the fifteen known employment histories, a third (thirty-three percent; $\mathrm{n}=5$ ) reported having no previous labour market experience. Over half (fifty-three percent; $n=8$ ) were previously employed, while two participants currently occupied paid positions.

In terms of family make-up, only one woman interviewed reported being currently married or involved in a common-law relationship, although information was unknown for nine participants. All of the women were mothers. Over half $(n=12)$ had five or more children (average=4.86). Of the sixteen participants who had infants, toddlers, or school-aged children, fifty-six percent $(n=9)$ currently had custody of all their children.

In an attempt to contextualize women's experiences with criminalization, we tried to gather information on the participant's life histories. Six women spoke of growing up in and out of foster care. Although not specifically probed for, six women disclosed occurrences of physical and/or sexual abuse as children and six participants identified experiencing domestic violence as adults. Four women spoke of being prostituted - two as adolescents. Some of the women interviewed also reported mental health struggles, being diagnosed with fetal alcohol syndrome, being bullied as youth, witnessing the deaths of close friends and family members, and being infected with HIV. Finally, all of the women interviewed disclosed struggles with drugs and/or alcohol and many spoke about the systemic and inter-generational nature of substance abuse within their families.

\section{B. What experiences do women in prison have that could or should be the subject of a legal review?}

At least seven of the women interviewed reported having been placed in segregation (solitary confinement in a tiny, concrete cell in the basement of the jail) for periods ranging from a few days to a number of weeks. Two women reported having been strip-searched, at least one with a male guard present:

...so him and this other guard took me down to the hole and made me strip down all my clothes in front of them. I was even on my time [menstruating] then, you know .... I was there for a month and a half. 
She went on to say:

[t] here's a mattress, a bed, a sink, a toilet. One time, I don't know how to say it, I threw a panic attack in there 'cause it was so small, and I was asking to see the nurse or if they could give me something for it, and still nothing. I was just lying there finding it hard to breathe. I was closing my eyes and crying and guards were just walking by.

One woman reported that she had been segregated for suspected drug possession and three others for fighting with other prisoners. At least one woman indicated that she had been placed in segregation "for her own protection" rather than for disciplinary reasons:

[l]ike they wanted me to go into segregation when I was having problems with these girls. I go down there, and I'm like, "will I get my phone calls?" And they're like "No, you're treated like the way you're supposed to be treated in segregation." And I'm like, you guys are telling me to do this stuff yet you guys won't help me out here so, you know, like I have to suffer through, you know, living like this, like you know scared for my baby. Like I know that I did things wrong, but they had no right to treat me like that. I made bad choices when I was younger, you know, when I was young, but that doesn't mean that I'm not a good human being.

One woman indicated that she was not told about any right to call a lawyer and was provided with no access to the phone. However, another woman reported having been told "do you want a lawyer or do you want to say something on your behalf?" when she appeared before the internal Disciplinary Board, presided over by the Deputy Superintendent and two other correctional staff members. ${ }^{57}$

One woman reported that a prisoner, whom she believed to be schizophrenic, was put in segregation for approximately two weeks:

[w] hen I was in there, there was a girl in there. She was one of my roommates in the room I was in. She had a problem. She was schizophrenic and the girls complained about her and they just came and took her from there and she didn't even do anything and they took her to the hole because she was a schizophrenic. She was there [segregation] for two weeks that I was there.

Other discipline reported by the women consisted of, for example, being confined to their cells for opening a door and hitting a guard or swearing at a guard.

Two women described having heard staff make offensive comments about Aboriginal women. For example, 
[o]ne guard said something [derogatory toward Aboriginal women] that I didn't like so I said something to her and I felt that I was punished for it. I don't want to repeat it...I told her you shouldn't be saying that to people.

A number of women served at least some of their time in "cell block" (PCC's "secure living location," which consists of small, segregation-type cells with barred doors that open up to a small, common eating area and is a more restrictive environment than the usual "dorm-style" cells). Three women reported having concerns about other women in the institution, fearing for their safety, and not feeling that they received an adequate response when they voiced these concerns to correctional staff.

Five women reported not receiving their medication for some period of time while at PCC and a number expressed a range of physical and health concerns that they felt were unaddressed by medical staff. The following two women described their experiences:

[w] hen I was in segregation] I was bitten by red ants... I tried to tell the nurse about it and all she gave me was calamine lotion. I was actually sick for about a few days... I had bites all over.

When I was there I didn't get my medication... I had an anxiety problem. I felt that that I just couldn't handle it day by day. Yes, they took my medication away. I found that very hard and stressful.

Four women described having been treated roughly or subjected to verbal abuse from staff. One woman reported not having been permitted to telephone her home in an emergency and another indicated that mail from her lawyer was opened by correctional staff:

[l]ike they open our lawyers' mail in front of us and I thought they weren't supposed to.

Assuming for the purposes of this study that the experiences described by the women could be proved through evidence, and recalling our brief review of legal rights and review mechanism in Part II, a number of rights and legal avenues for review potentially arise. The incarceration of prisoners in segregation (whether for disciplinary or administrative reasons) triggers rights related to institutional complaints and reviews provided under the CSA and Regulations, as well as rights to fair procedures in accordance with the "principles of fundamental justice" protected by section 7 of the Charter. ${ }^{58}$ Strip-searching may implicate rights under section 8 of the Charter (freedom from unreasonable search or seizure), even though pris-

58 See e.g., Howard v. Presiding Officer of the Inmate Disciplinary Court of Stony Mountain Institution, [1984] 2 F.C. 642 (C.A.) and Pickard v. Mountain Institution, [1994] F.C.J. No. 438 (T.D.).. 
oners have been held to have a diminished "reasonable expectation of privacy" in prison. ${ }^{59}$ The protections against discrimination found in the Human Rights Code and section 15 of the Charter mean that, for example, any discriminatory treatment of Aboriginal prisoners or the presence of male guards on the front lines in women's prisons (including during a strip-search), could form the basis for human rights claims. ${ }^{60}$ At a broader level, each of the experiences described above could be the subject of a complaint to the Ombudsman for investigation.

\section{Do women in prison utilize existing legal mechanisms for redress of rights violations and other illegalities? Why or why not?}

Women who participated in the study demonstrated a low level of utilization of any internal or external complaint and/or review mechanisms. One woman reported grieving a decision to the Superintendent of PCC, and a handful of women indicated having made calls to the Manitoba Ombudsman. However, only two women reported having submitted any kind of written complaint to the Ombudsman. One of these women described Ombudsman staff as having been very helpful to her.

According to the 2006 Annual Report of the Manitoba Ombudsman, there were sixteen new cases opened that year from women at PCC. ${ }^{61}$ The number was similar in 2005, with fifteen new cases. ${ }^{62}$ Neither the 2005 nor 2006 Report, provides any information about the circumstances of these complaints. In the past, the Ombudsman has investigated and made recommendations on a variety of issues, including in a series of reports concerning health care at PCC in 2001, 2002, and 2004. ${ }^{63}$ The total number of new cases opened by the Ombudsman in 2005 for all government departments or agencies was 718, with 260 of those involving various aspects of Manitoba Justice (the majority being from corrections, with others relating to legal aid, maintenance enforcement, etc.). In 2006, the total number of new cases was down to 314, with 114 concerning various aspects of Manitoba Justice.

Our finding that relatively few complaints are made by women prisoners seems consistent with these statistics. A number of possible explanations for this relatively low level of utilization emerged from the interviews, namely:

- first, women lacked information about their rights as prisoners and any legal mechanisms available for complaint and redress;

- second, women faced a number of practical barriers to the use of any legal mechanisms, such as barriers related to literacy levels, their relatively short stays, a lack of legal aid, etc.;

59 Fieldhouse v. Canada (1995), 40 C.R. (4th) 263 (B.C.C.A.).

60 See CHRC, Protecting Their Rights, supra note 5 at 5.2.1.1. for a preliminary discussion of the human rights issues associated with male guards on the front lines in women's prisons.

61 Manitoba Ombudsman, 2006 Annual Report (March 31, 2007), online: Ombudsman Manitoba <http://www.ombudsman.mb.ca/whatsnew.htm>.

62 Manitoba Ombudsman, 2005 Annual Report: Administrative Accountability (March 31, 2006), online: Ombudsman Manitoba <http://www.ombudsman.mb.ca/whatsnew.htm>.

63 Manitoba Ombudsman, 2004 Annual Report: Administrative Accountability (May 31, 2005). 
- third, women just "did their time," feeling that making a complaint would be futile; and

- fourth, women feared reprisals (either from other prisoners or from correctional staff) if they used any legal mechanisms.

In the paragraphs that follow, we discuss each of these possible explanations in turn.

\section{Lack of Information}

All but one of the women interviewed felt they were not adequately informed of their legal and human rights while they were in prison. Some of the comments include:

[t] he only rights I heard were when I was getting arrested. They never explained anything in jail.

I heard about the Ombudsman but I didn't know how to access that but my cousin did.

I never tried 'cause I didn't know anything.

No I don't much about it [legal resources and rights] 'cause I've never been in this justice system before.

... because I didn't know anything and I don't know, I just wanted to get the hell out of there.

At least one woman reported having been told that she had no rights:

[t] here was this lady guard... They told me once you are in here you are a nobody. You don't have no rights. I asked them "don't I have a right to talk to someone?" They said "no, not once you are in here you are nobody. You don't have no rights."

Another woman described not being advised of her rights:

[i]n my personal opinion we are not advised of our rights. ... I think the government... I don't know if it is the government or the people who run PCC, whatever, it's just they don't advise us because then they don't want us to know how to go about getting these rights.

However the same woman also noted that

[t] here is a paper by the phone that states if you have a problem...No one ever told me about the Ombudsman. I read it. They keep it posted. 
The first ever newsletter of the Manitoba Ombudsman, published in December 2006, describes some new initiatives aimed at increasing the awareness of provincial prisoners and correctional staff concerning methods to address complaints. The office has produced new pamphlets and posters entitled "How to Solve Problems While in Provincial Jails" after consulting with prisoners and staff at various adult and youth correctional centres in the province. The Elizabeth Fry Society of Manitoba has learned that staff from the Manitoba Ombudsman periodically come to PCC to hold information sessions with the women. This would seem to be a positive and productive initiative. However, it is not clear how often these information sessions take place. In addition, complaints to prison officials or to the Ombudsman are only two mechanism in the array of legal rights and review mechanisms provided by law, as outlined in Part II. For example, the women interviewed demonstrated no awareness of any Charter rights that might be violated while they were in prison and that might form the basis for a potential claim in court.

\section{Practical barriers to making complaints}

One woman described the disincentive to make any complaint, given that her stay in jail would not be very long:

$[w]$ hen you put a request in it takes a while. It takes maybe a week, two weeks and I knew that I wasn't going to be there long so... Not arguing about anything. I'll just do my time and get out.

Most women interviewed had low levels of formal education. As such, some women described having difficulties understanding written material about their rights, indicating that they would understand better if things were explained to them in plain language. Some also described the posters and pamphlets being ripped down and not replaced.

I only went to grade eight and I don't know all these big words.

Not like by book but by talk. Because I don't understand the words.

Get someone to come in and talk about these things... because the papers get ripped down, you know.

\section{Lack of confidence in the system and just "doing their time"}

Many women reported that they felt complaints were futile, or that they would not be treated fairly, so they just "did their time":

[y] ou can complain all you want, they don't do nothing. They don't care... There is nothing you can do. They don't do anything. You complain and complain and nothing gets done [in particular, in relation to health care concerns]. 
We can go to the Ombudsman. We know that but there is no point. They don't do anything. Because you complain and it doesn't work. Nothing happens. Nothing gets changed. When you get in, right, you get this booklet that says if you want to complain then you go to the Ombudsman, right. Well, it doesn't matter because nothing gets done. Nothing changes.

Keep your mouth shut and this will go faster... I'll keep my mouth shut so you can do your job.

I figured that I would lose and they would do nothing.

Even a woman who identified herself as "headstrong" felt defeated by the prospect of making a complaint:

I tried but it's no use because it's like useless unless you're really headstrong like I can be. But not for so long, 'cause they, like, take everything out of you and you get things taken away. Like, there's not much to be taken away but that's all you got you know. You don't want stuff like that taken away when you already have nothing.

One woman who indicated she had called the Ombudsman described feeling abandoned:

[y] es, I do. Yes, I phoned the Ombudsman and you know they are so hard like to deal with. Like last year I had talked about complaining about my phone privileges... after that I had also accepted it but I also said like this is too long... as soon as I walked in that gate they said you don't have your phone privileges. I said like that was last year and I said so what's the difference now... All I did was cry. I called them and they told me that... write to the ombudsman which I had... like nobody even came in to talk to me but like nobody ever even called or cared about anything.

However, another woman described having successfully complained to the Superintendent about her concerns regarding medical care:

I wrote a letter to the higher lady, the warden. They ended up doing something about it.

\section{Fear of reprisals}

A number of women described feeling too scared to make a complaint, expressing concerns about possible reprisals from correctional staff or other prisoners for "ratting". According to one woman:

[a] lot of women are afraid to ask questions so if that kind of information was already there it would make it easier for them 
to get that kind of legal information. It would help them know what their rights are. That was one of the things we discussed in there. There were women from all different reserves and we talked a lot about that but we couldn't find a solution. I told them that because of the abuse we suffered in our childhood that we were all afraid of repercussions, that if we told anyone about our abuse that we felt it would only get worse.

Other women expressed similar concerns:

I didn't want the girls to call me a rat and try to roll me out.

I was too scared. They give you a harder time if you do something like that [file a complaint].

No I didn't because I was afraid of repercussions, like when I shared that story with you [she had described organizing women in her home community to protest a violent attack on a friend and she had experienced negative treatment in the community]... So for me doing that I felt a lot of repercussions from that. So I felt that if I took my complaint to an ombudsman that there would be repercussions. I'm still afraid of that.

One woman described having learned from her sister, who had also done time at PCC, that it was better not to speak up:

I felt angry so I didn't want to screw up... Well, my sister was in there for like 2 years and she said she went in there [segregation] once because she spoke up.

Our findings in this study are constant with what the Manitoba Aboriginal Justice Inquiry found to be true 15 years ago, at least with respect to the provincial jail system for women:

[i]n both federal and provincial penal systems in Manitoba, there exists no satisfactory, culturally appropriate process for Aboriginal inmates to challenge or appeal their treatment. According to our survey of inmates, $64 \%$ of Aboriginal inmates had not made any complaints during their time in prison, compared with $40 \%$ of non-Aboriginal inmates. Thirty per cent of Aboriginal inmates felt there was no one they could go to with complaints about the way they were treated, and this figure rises to $41 \%$ when one looks only at provincial Aboriginal inmates. Sixty-nine per cent of those who did make their complaints known reported that their concerns were ignored. ${ }^{64}$ 
In the next section, we explore some of the ideas and recommendations arising from this preliminary research. However, it remains the case that further research would assist in shedding light on possibilities for addressing some of the practical barriers to utilizing internal or external complaint and review mechanisms, such as the short prison stays and the speed with which disciplinary decisions and sanctions play out in provincial systems. We suggest that it would be most beneficial to conduct action-oriented research through, for example, prisoners' legal clinics operated in partnership by Legal Aid and university researchers and students. Such clinics would provide much-needed legal information, advice, and support with prisoners' claims, while also allowing for additional research in a community-based setting.

\section{RECOMMENDATIONS AND POLICY DIRECTIONS}

A number of recommendations emerge from the women's experiences and knowledge, when considered in conjunction with findings from other research and reports. ${ }^{65}$ They range from relatively simple proposals such as providing regular, accessible information about existing rights, along with greater cultural supports and access to legal aid, to calls for new, independent accountability and oversight mechanisms to promote rights enforcement and ensure compliance with the law in provincial jails.

\section{A. Better information about existing rights}

Given that so many women indicated that they did not understand their rights, it is not surprising that a number of them recommended better orientation on, and information about, their rights. Due to lower levels of literacy and inadequate education experienced by these women, it was clear from the interviews that the answer does not lie in simply putting up more posters or giving out booklets. In addition, due to the high level of turnover, and relatively short stay of most provincial prisoners, regular and recurring orientation on rights is required. According to two of the women interviewed:

[t] hey need to be told or shown how to fill out a complaint... Once a week you should hold a gathering once a week as a group together... and hand out pamphlets about their rights: "This is what you can do if you feel your rights have been violated or have you been given a chance to do any of this?" Give them the numbers of lawyers where they can complain, where they can do that. Native, Aboriginal women. There are a lot of women who do not know their rights and they should be aware and shown how to get better aid, legal aid that way.

They should have some kind of liaison officer. Whether it be

65 See e.g., Hamilton and Sinclair, supra note 6; CHRC, Protecting their Rights, supra note 5; and various articles collected in the symposium "Prison Oversight and Human Rights," (2006) 48 Canadian Journal of Criminology and Criminal Justice at 127-314. 
through the government or PCC or whoever to sit there and have an orientation when you first get there. There is an orientation that takes place now where rules and regulations are told but they should also have another orientation where women are informed of their legal and human rights. A lot of women do have conflict with the guards and whatever and there are certain rights that $I$ am sure we are not given.

It is hoped that the plain language handbook produced as part of this research project, as well as the new materials developed by the Manitoba Ombudsman, will go some way toward filling this information gap. However, broader systemic changes, along with human advocacy and legal resources are also needed, as discussed below.

\section{B. Accessible and knowledgeable advocates}

The women's call for more accessible and frequent information about their rights is related to a second recommendation for knowledgeable advocates, including lawyers, community advocates, or others, who would meet confidentially with the women. The women linked their awareness (or lack thereof) of their rights and access to justice to the broader social context of marginalization they experience. They described the importance of advocates in a variety of ways:

I think they should have individual counseling in there. Let you know the rights you have. Because a lot of girls that go in there, they're first time. They don't know. They are scared to even ask for help.

I wish there would be somebody there like to check up on the inmates in there.... There should be someone there like to go talk to the inmates, 'cause there's a lot of times there when the girls in there need to talk to somebody.

I think... they should have somebody like you [interviewer from Elizabeth Fry Society] there to help. Along with pamphlets and stuff.

I think that somebody should go in there and explain to them what their rights are and why they're allowed these rights, and what they can do and stuff like that, without a guard sitting there. You can't go and explain anything because you have two, three guards sitting there, which makes it very uncomfortable, because you really can't talk about anything because they're there.

I came to [meet with] Elizabeth Fry when I was in Remand and when I was getting out the first time.

I feel that lawyers should go out there and visit with the women when they're in there. 
They should have somebody there like you over there that you can talk to. In the jail, so you can talk to them. [Someone] that goes in there, like, every week. Have everything confidential.

A 2002 Report of the federal Department of Justice entitled "Six Degrees from Liberation: Legal Needs of Women in Criminal and Other Matters" "came to a similar conclusion, namely that:

$[\mathrm{m}]$ ost basically, prisoners require legal information in order to assist them to frame a problem as one with a legal dimension to it. Given the cultural alienation most federally sentenced women experience, legal information would be most easily accepted if it were authored and distributed by such community-based organizations as Elizabeth Fry Societies. Other organizations that could bridge the cultural divide with Aboriginal women or offer information in an accessible format to women with mental health challenges would be able to assist women to identify their legal issues as well as the recourses available to them. ${ }^{67}$

\section{Aboriginal spiritual and cultural supports}

A key theme that arose in a number of interviews was the importance of support from elders, sharing circles, and greater access to cultural supports for incarcerated women. The provision of such services within provincial jails was a significant recommendation of the Aboriginal Justice Inquiry, and one that has been implemented to a certain extent. ${ }^{68}$ Elders provide some support to women prisoners at both the Winnipeg Remand Centre and PCC, although women interviewed for this study indicated that the demand for elder services often exceeds their availability.

Some women indicated that participation in sharing circles and the support of elders assisted them in asserting their rights and regaining their confidence. Some of their comments include:

\section{I believe that [we need] things like sharing circles where you can}

66 Addario, Six Degree from Liberation, supra note 4.

67 Ibid. at 2.2.2 "Legal Aid and Other Legal Needs." See also, Prairie Research Associates Inc. (PRA), Study of the Legal Services Provided to Penitentiary Inmates by Legal Aid Plans and Clinics in Canada (Ottawa: Department of Justice Canada, Research and Statistics Division, 2002) www. justice.gc.ca/en/ps/rs/rep/2003/rr03lars-10/rr03lars-10.pdf in which it is noted (at 3.5.2):

$[w]$ hile this research has concentrated on legal aid, it is clear that there are other important related legal supports that can be provided to federal inmates. Legal orientation sessions for new inmates, toll-free legal advice services, and well-maintained law libraries in correctional institutions can provide a cost-effective supplement (or even an alternative) to legal aid, especially in light of past and potential cuts to legal aid funding. These related forms of support should also be available in a range of media to reflect the varying needs and abilities of federal inmates.

68 Hamilton and Sinclair, Justice System and Aboriginal People, supra note 6 at c.11. 
talk and where you can share each other's stories. I believe it empowers women; they become stronger and more confident. I would like to see a place for them to share their stories. Because a lot of time just talking about it can make you feel better and not so alone. I would like to see a lot more of elder participation. Like in there we were fighting over one elder.

They should ... have meetings where they can sit with other people and sit and have coffee and talk.

Like you have to grab a hold of a lot of things, like you grab a hold of $A A$ and that, and you know that when I've been out here [out of jail] I grabbed a hold of my [Aboriginal] culture and I think they need more of the cultural things in jail. Like, you know, they don't have none of that and a lot of them are just lost, like I was lost.

I think that most women are Aboriginal and I think they need to be more in touch with their spiritual background and their spiritual culture.

An example of a model that might be considered in Manitoba is the national "Human Rights in Action" collaboration between the Canadian Association of Elizabeth Fry Societies, the Native Women's Association of Canada, and Strength in Sisterhood, an organization of former women prisoners. This partnership, funded by Status of Women Canada, has involved the training of prisoner peer advocates, Aboriginal women in the community, Elizabeth Fry Society staff and others to form advocacy teams to promote awareness of the human rights and reintegration needs of federally sentenced women, with a particular focus on the needs and capacities of Aboriginal women.

\section{Independent oversight and accountability}

The finding from this study that many prisoners lack confidence in the complaints process is consistent with other research at the federal level and points to the reality that simply improving information and advocacy within the existing internal complaints process will not be enough to achieve access to justice. As described above, correctional law in Manitoba provides for wholly internal complaint, segregation review, and discipline procedures, which is a common model across Canadian provincial systems. In the federal system, experience has shown that internal accountability for compliance with the law has not provided sufficient protection against abuses within prisons. ${ }^{69}$ The inadequacy of the federal grievance procedure, including its lack of procedural fairness guarantees, delays,

69 See for example, the articles collected in the recent symposium on "Prison Oversight and Human Rights" in (2006) 48(2) Canadian Journal of Criminology \& Criminal Justice. See also Canadian Human Rights Commission, supra note 6 at c. 8: "Protecting human rights requires effective external redress." 
and failure to address long-standing issues, has figured prominently in every annual report of the federal Correctional Investigator since fiscal year 1987-88. After much careful investigation and review, Justice Arbour concluded in 1996 that internal accountability mechanisms were incapable of effectively requiring that prisons conform to the Rule of Law. She urged that the Correctional Service of Canada [CSC] "would be well advised to resist the impulse to further regulate itself by the issuance of even more administrative directions. Rather, the effort must be made to bring home to all participants in the correctional enterprise the need to yield to the external power of Parliament and the courts. ${ }^{30}$ There is no reason to believe that the situation is any better in the provincial context.

In response to concerns about the lack of independent decision-makers in the federal institutional discipline system, the CSC has instituted Independent Chairpersons for disciplinary hearings. ${ }^{71}$ Recently, a provincial jail discipline regime in Alberta (which is similar to that in Manitoba) was declared unconstitutional for its lack of independence by the Alberta Court of Queen's Bench. The Court in Currie v. Alberta (Edmonton Remand Centre), ${ }^{72}$ found that the disciplinary board failed to meet the requirements of independence required by s. 7 of the Charter. There was found to be a clear conflict between the duty of staff members of a disciplinary board in Alberta's correctional centres to maintain discipline and staff morale and the right of prisoners have charges dealt with before a tribunal with a sufficient degree of independence and impartiality. This conflict of interest led to a reasonable apprehension of bias in a substantial number of cases. The court went on to hold that while training board members (i.e., correctional staff) in administrative law would assist in achieving procedural fairness, it could not remove the inevitable bias in favour of the evidence of correctional officers. Furthermore, even though granting prisoners the right to counsel and the presence of counsel at hearings would help to achieve procedural fairness, the reasonable apprehension of bias would remain. Both the discipline board process and appeal processes were found to violate the Charter. ${ }^{73}$

Given the similarities between the Alberta and Manitoba institutional discipline regimes, it is reasonable to conclude that a constitutional challenge in Manitoba would have a similar likelihood of success. The key problem, from a Charter perspective, is the lack of independence and the resulting reasonable apprehension of bias. This lack of independence was criticized in the Manitoba Aboriginal Justice Inquiry Report:

[h] earings are conducted by a senior staff member of the institution. This, we believe, creates a conflict of interest situa-

70 Arbour, ibid., at 181 .

71 For a discussion of the development of this model, including on-going deficiencies in the federal discipline system, see Michael Jackson, "The Litmus Test of Legitimacy: Independent Adjudication and Administrative Segregation” (2006) 48 Canadian Journal of Criminology and Criminal Justice 157 at 187-200 [Jackson, “The Litmus Test”].

72 (2006), A.J. No. 1522 (Q.B.).

73 Since the legislation would have to be amended to comply with this ruling, the court suspended the declaration that the law was unconstitutional for a one year period to give the government time to change the law. The decision was rendered on December 1, 2006. 
tion, both apparent and real. These disciplinary "trials," for that is what they are supposed to be, breach the rules of natural justice. ${ }^{74}$

Finally, the wholly internal nature of the provincial segregation review process is a serious concern. In his recent article urging the implementation of independent adjudication of all segregation decisions in federal prisons, Michael Jackson stated:

[b]ecause the time spent in administrative segregation can extend to months, even years, it represents the most powerful form of carceral authority. Because the conditions of confinement are the closest thing to solitary confinement, it is also the most intensive form of imprisonment. Historically, it has been the most abused. ${ }^{75}$

Jackson concludes by stating,

[i]t remains my conviction, based on 30 years of research, that independent adjudication of segregation is necessary to ensure a fair and unbiased hearing, compliance with the statutory framework, protection of prisoners' rights and privileges during segregation, and the implementation of reintegration plans to ensure that the correctional authorities, in administering the sentence, use the least restrictive measures. ${ }^{76}$

Jackson suggests that the courts may intervene to order independent review of segregation, if such a regime is not voluntarily implemented by federal correctional officials.

Fifteen years ago, the Manitoba Aboriginal Justice Inquiry made the following recommendations concerning access to justice for Aboriginal prisoners:

We recommend that:

Rules for disciplinary hearings in correctional institutions be clarified and enforced to permit an inmate to have a friend or lawyer present to assist at the hearings and to guarantee the opportunity to make full answer and defence to a charge.

Disciplinary hearings in correctional institutions provide for fair adjudication by having an independent third party preside over the hearing and ensure the rules of natural justice are followed.

74 Hamilton and Sinclair, Justice System and Aboriginal People, supra note 6 at c. 11.

75 Jackson, "The Litmus Test", supra, note 71 at 158.

76 Ibid. at 191. 
An independent tribunal be established to adjudicate inmate complaints about the treatment they receive within the correctional system; and that the tribunal have appropriate resources and authority to investigate complaints, mandate change and enforce compliance with its orders. ${ }^{77}$

Our findings in this study confirm the need to implement these and other related measures to provide meaningful access to justice for prisoners in Manitoba. A number of components of an accountability and oversight strategy are discussed below.

\section{Independent prison inspectorate to augment complaint-based systems}

Given the relatively short length of provincial incarceration, effective firstinstance and proactive independent review processes are even more important than at the federal level. To this end, the introduction of an independent inspector general to monitor the ongoing conditions of confinement experienced by women prisoners and to promote compliance with the law should be explored. In the interviews conducted for this study, one woman pinpointed the need for proactive inspections, rather than relying wholly on a complaint-based system, saying:

I wish there would be somebody to check up on the inmates in there.

Another woman commented:

$[w]$ e need to have the Ombudsman really investigate and really do some changing.

The reality is that, even if the Ombudsman finds merit in a prisoner's complaint, the only recourse is to make a recommendation to government. Consistent with an ombuds function, there is no legal authority to order compliance. In the federal context, a woman prisoner commented to the Canadian Human Rights Commission about this reality, saying "It would be good if the Correctional Investigator had power because as it now stands it is just venting to talk to the Correctional Investigator." 78 The need for mechanisms to ensure compliance with the law and to provide remedies for rights violations will be discussed further below under "access to judicial remedies and enforcement of rights." However, the other characteristic of an ombuds function alone is that it is reactive and complaint-based rather than proactive and systemic.

To augment the work of a prison ombuds office, jurisdictions such as the United Kingdom and South Africa have implemented independent prison inspectorates. The English model is described by the Canadian Human Rights Commission in its 2003 Report:

77 Hamilton and Sinclair, Justice System and Aboriginal People, supra note 6 at c.11.

78 CHRC, Protecting their Rights, supra note 5 at c. 8. 
[e]xternal monitoring bodies are common in other countries. The Chief Inspector of Prisons for England and Wales conducts approximately 20 full inspections each year and is concerned with issues of broad impact, rather than individual complaints. This stands in contrast to the primary function of the Office of the Correctional Investigator which is to investigate and resolve individual offender complaints. Although the Office of the Correctional Investigator also has responsibility for reviewing and making recommendations on the Correctional Service's policies and procedures relating to individual complaints, the systemic impact of this function is limited by the lack of enforcement powers. In England and Wales, there is also a Prison Ombudsman who is charged with receiving complaints on all matters relating to prison and probation, with the exception of parole decisions. ${ }^{79}$

Such an inspectorate in the Manitoba context would augment, rather than replace the complaint-based function of the Ombudsman. To be effective, the inspectorate would have to be provided with the mandate and requisite resources, including the financial means, to conduct annual audits of institutional adherence to governing legislation and policy within correctional facilities for adults and youth in Manitoba (in addition to conducting unannounced inspections) with the audits submitted to the Legislature.

\section{Access to judicial remedies and enforcement of rights}

Finally, it is trite to note that rights without remedies are meaningless. To promote compliance with the law and remedies for breach of the law, access by prisoners to the courts or to an independent administrative tribunal is necessary. The latter option has been discussed by the Canadian Human Rights Commission in the federal context and could be adapted for Manitoba:

[o]ne option is to establish an administrative tribunal with the power to compel the Correctional Service to comply with legislation and policy governing the administration of sentences, and to redress the negative effects of non-compliance. The remedial powers of such a tribunal would also include the jurisdiction to order the Correctional Service of Canada to pay compensation to any offender subjected to illegal or unfair treatment. With the jurisdiction to accept direct references from prisoners or their advocates in cases that raise issues of general importance to prisoners, the tribunal could effect more widespread and systemic change than currently exists. It could be part of an existing structure, such as the Canadian Human Rights Tribunal. ${ }^{80}$

79 Ibid., at Chapter 8. See also the website of Her Majesty's Inspectorate of Prisons (England and Wales) online: HMI Prison <http://inspectorates.homeoffice.gov.uk/hmiprisons/about-us/>.

80 CHRC, Protecting their Rights, supra, note 5 at c. 8. 
The federal Office of the Correctional Investigator has made a similar recommendation ${ }^{81}$ while also expressing its support for judicial remedies including the so-called "Arbour Remedy." Ten years ago, at the end of her lengthy commission of inquiry into abuses at the Prison for Women as noted earlier, Justice Arbour concluded that a judicial remedy for rights violations is necessary to enforce the Rule of Law inside prisons. Justice Arbour recommended legislative implementation of the following principle:

[i]f legalities, gross mismanagement or unfairness in the administration of a sentence renders the sentence harsher than that imposed by the court, a reduction of the period of imprisonment may be granted, such as to reflect the fact that the punishment administered was more punitive than the one intended. ${ }^{82}$

Such a remedial power is consistent with the judicial functions of habeas corpus review of illegal detention and Charter review of police and other government action to ensure that non-compliance with the law is effectively sanctioned and deterred. As Justice Arbour noted, the proposed remedy would be similar to s. 24(2) of the Charter which empowers - and indeed, requires - judges to exclude illegally-obtained evidence from a criminal trial, sometimes leading to an acquittal or stay of proceedings. The courts' exercise of that power has been, in Justice Arbour's view, "the single most effective means ever in Canadian law to ensure compliance by state agents with the fundamental rights in the area of search and seizure, arrest and detention, right to counsel and the giving of statements to persons in authority." 83 It has changed police behaviour because there is a "real and understood social cost of allowing a potentially guilty accused to escape conviction." ${ }^{44}$

In making her recommendation for judicial oversight to remedy interference with the integrity of the sentence, Justice Arbour addressed the concern that such a remedy would be an undue burden on an already stretched court system. She noted that any additional burden "would only be so in relation to the Correctional Service's non-compliance with the law," ${ }^{\prime 5}$ pointing out that there are ways to control frivolous litigation, should such a problem arise.

The context of provincial imprisonment, where sentences are short, presents additional challenges. However, we have seen a few instances of judges effectively filling the remedial gap in enforcing prisoners' rights. For example, Norman MacPherson, ${ }^{86}$ a provincial prisoner in New Brunswick brought a successful

81 Office of the Correctional Investigator, Shifting the Orbit: Human Rights, Independent Review and Accountability in the Canadian Corrections System (Ottawa: Office of the Correctional Investigator, 2004) at 32 online: Office of the Correctional Investigator <http://www.oci-bec. gc.ca/reports/pdf/orbit-orbite_e.pdf>.

82 Arbour Report, supra note 9 at 183.

83 Ibid. at $188-184$.

84 Ibid. at 184 .

85 Ibid.

86 R. v. MacPherson, [1996] N.B.J. No. 182 (S.C.). See Mary Campbell, "Gone But Not Forgotten: Should Judges Be Allowed to Remedy at Re-sentencing?” (2006) 48 Canadian Journal of 
habeas corpus application after he was strapped face-down on a stretcher with a hockey helmet and wire mask over his head for two to three hours. The Court found that he was treated in this manner as punishment for banging on his cell door repeatedly and requesting to call a lawyer. The treatment of MacPherson amounted to violations of his s. 12 and 9 Charter rights, as well as showing "limited recognition of his right to retain and instruct counsel under s. 10(b) of the Charter." The court found that MacPherson had been asking to call a lawyer for at least 40 days but had not been permitted to do so. Charter remedies ordered by the court included, notably, a reduction of three months from MacPherson's sentence, as well as an exhortation that the provincial Attorney General "consider what steps can be taken to ensure that legal aid is readily available to inmates of jails in New Brunswick." This latter comment leads to our final recommendation.

\section{E. Increased access to legal aid for prisoner}

The nature of the interests at stake, combined with the complexity of redress mechanisms and court proceedings for prisoners, means that legal aid must be a component of any access to justice strategy. As described above, prisoners have a legal right to access the superior courts for judicial review by way of habeas corpus on Charter or administrative law grounds, or to challenge breaches of correctional law, a right recently reaffirmed by the Supreme Court in May v. Ferndale Institution. ${ }^{87}$ However, rights to counsel in the prison context are often more illusory than real when one considers that provincial legal aid systems across the country provide uneven and inadequate coverage for prisoners' cases in the federal penitentiary context, ${ }^{88}$ with even fewer services available to prisoners in provincial jails. The Supreme Court of Canada has not yet addressed the question of whether prisoners have a free-standing, constitutional right to legal aid where deprivations of their liberty and other rights violations are concerned. However, the reality is that for the vast majority of prisoners who are poor, access to meaningful redress of their rights will require some access to legal aid.

Currently, Legal Aid Manitoba does not fund or operate legal clinics in the provincial jails, but it has funded some significant prisoners' rights cases on an ad hoc basis through the Public Interest Law Centre [PILC]. For example, PILC acted for the Elizabeth Fry Society of Manitoba in a Human Rights complaint the organization filed in 2002 on behalf of women prisoners in the province. The complaint alleged systemic discrimination on the basis of sex, race, and disability concerning the facilities and conditions of confinement at PCC, including, for example, inadequate programming to address women's needs, inadequate access to Aboriginal spiritual and cultural practices, and inadequate opportunities to

Criminology and Criminal Justice 305 at 310. Campbell notes that this case is the "closest that a litigated remedy has come to the Arbour Report recommendation" for a reduction in sentence as a remedy for prisoners' rights violations.

87 May v. Ferndale, supra note 38.

88 Department of Justice Canada, Study of the Legal Services Provided to Penitentiary Inmates by Legal Aid Plans and Clinics in Canada (Ottawa: Department of Justice Canada, 2002) online: Department of Justice <http://canada.justice.gc.ca/en/ps/rs/rep/2003/rr03lars-10/index.html>. 
meet with their families and lawyers. ${ }^{89}$ PILC also acted for federally sentenced prisoners at Stony Mountain Institution in their successful Charter challenge to the law barring them from voting in federal elections..$^{90}$ In addition, Legal Aid Manitoba provides some limited services to federal prisoners facing disciplinary hearings at Stony Mountain Institution, often through utilizing articling students and law students.

These developments, as well as those in other provinces, indicate that innovative approaches to providing legal services to prisoners can and should be developed. For example, in British Columbia, a non-profit society, West Coast Prison Justice Society [WCPJS], was formed after cuts to legal aid in that province forced the closure of a specialized clinic, Prisoner Legal Services. The Clinic now operated by WCPJS receives a minimal level of legal aid funding from the province to provide services "as required under the Canadian Charter of Rights and Freedoms." ${ }^{\text {91 }}$ Legal Aid Ontario has a Prison Law Advisory Committee and a Test Case Committee. Through the Test Case Committee, Legal Aid Ontario funds cases in the correctional context, upon application by lawyers interested in bringing such cases. ${ }^{92}$

Prison law is a specialized area that is unfamiliar to most lawyers, including experienced criminal lawyers. To provide meaningful access to justice for Manitoba prisoners, the possibility of establishing a specialized Prison Law clinic, with services to both federal and provincial prisoners, should be explored. It may be possible to partner with the Faculty of Law, University of Manitoba, as well as with community groups such as the Elizabeth Fry Society or the John Howard Society. As an innovative example, with the assistance of the Law Foundation of Ontario, the Canadian Association of Elizabeth Fry Societies and the Faculty of Law (English Common Law) at the University of Ottawa have recently col-

89 In June 2007, the parties reached a mediated settlement which, among other things, commits Manitoba Corrections to implement mandatory human rights training for staff and prisoners and to co-chair with the Elizabeth Fry Society a new Women's Program Advisory Committee which will bring together community groups to provide input on women-centred and culturally-appropriate programs and services at all existing and proposed correctional facilities for women. More information and the full text of the mediation settlement agreement is available on the Elizabeth Fry Society of Manitoba website online: Elizabeth Fry Society <http://www. efsmanitoba.org/>.

90 Sauvé, supra note 18.

91 Legal Services Society of British Columbia, Fact Sheet (19 June 2006) online: Legal Services Society of British Columbia <http://www.lss.bc.ca/assets/newsroom/fact_sheets/LSS_servicessummary.pdf>. Recently, WCPJS has launched a "Prisoners' Human Rights Project" on a pilot basis, with a grant from the Law Foundation of British Columbia. The goal of the project is to provide legal assistance (through lawyers and paralegals) on human rights and health care matters, having found that there is a need for expanded legal services for prisoners:

Our initial foray into complaints about human rights violations and inadequate health care in $\mathrm{BC}$ prisons paints a disturbing picture of institutionalized rights abuses and a standard of medical treatment that the medical community would not permit outside the walls of BC prisons: WCPJS, Prisoners' Human Rights Project, Activity Report to the Law Foundation of British Columbia (August 1, 2007 to January 31, 2008), on file with author.

92 See the list of possible cases developed by the Prison Law Advisory Committee at "Information for Lawyers: Possible Test Cases - Correctional Law” online: Legal Aid Ontario <http://www. legalaid.on.ca/en/info/test_case-correctional.asp>. 
laborated on a pilot project to develop a manual for law students to provide legal advice to federally sentenced women prisoners via a toll-free telephone line. ${ }^{93}$ Such initiatives can be effective in building capacity among law students and lawyers to develop expertise in prison law and to assist prisoners in a variety of contexts (including reviews of segregation, disciplinary hearings, grievances, human rights complaints, and judicial review on habeas corpus grounds). They can also provide an opportunity for further research by students and university researchers' additional legal reforms that could better promote access to justice for imprisoned women and their families.

\section{CONCLUSION}

Prisons, like other closed institutions, pose accountability challenges for democratic societies. ${ }^{94}$ They have as their raison d'être the deprivation of peoples' liberty and, despite the best intentions, a virtually limitless potential for abuse. In this environment, "the law serves as a crucial counter-weight to the natural drift" toward callousness and brutality. ${ }^{95}$ Yet we have learned that despite the existence of a strong Charter of Rights and Freedoms, the Rule of Law has not effectively taken hold within our prisons and jails. As Justice Arbour remarked pointedly over ten years ago in relation to the federal Prison for Women, "[ $t$ ]he Rule of Law is absent, although rules are everywhere." 96 She went on to warn:

[o]ne must resist the temptation to trivialize the infringement of prisoners' rights as either an insignificant infringement of rights, or as an infringement of the rights of people who do not deserve any better. When a right has been granted by law, it is not less important that such a right be respected because the person entitled to it is a prisoner. ${ }^{97}$

Recommendations for independent accountability and oversight of certain aspects of corrections in Manitoba were made in the Aboriginal Justice Inquiry over fifteen years ago. Until the instant research was conducted through the Elizabeth Fry Society of Manitoba, there had been little discussion of the access to justice needs of provincially-sentenced prisoners. This community-based participatory research has provided an opportunity to bring the voices of prisoners into public and policy debates over allocation of legal aid and other government resources, as well as accountability and oversight of prisons. Their voices highlight the need for greater awareness of rights, effective first-instance procedures, and increased confidence in the fairness of any review mechanisms that, it seems, will only come through developing models of oversight and accountability that

93 Personal correspondence with Kim Pate, Executive Directors of the Canadian Association of Elizabeth Fry Societies (May 1, 2007).

94 Richard Harding, "Inspecting Prisons," in Yvonne Jewkes, ed., Handbook on Prisons (Cullompton: Willan, 2007) 543-546 at 543.

95 Campbell, supra note 15 at 327.

96 Arbour Report, supra note 9 at 181.

97 Ibid. at 182. 
are truly independent of corrections. The small number of women prisoners, relative to men, provides an opportunity to pilot new models of oversight and accountability, provision of legal aid, and community supports to learn what will result in better access to justice in this context. Further community-based research of this kind can also serve to build capacity, particularly among Aboriginal community members and organizations, to provide information about rights, as well as cultural and legal supports for prisoners exercising their rights. 